\title{
Analisis Beban Kerja Pegawai Pada Kantor UPBJJ-Universitas Terbuka Bandung
}

\author{
Bambang Agus Diana ${ }^{1}$ \\ Ridho Harta ${ }^{2}$
}

\begin{abstract}
ABSTRAK
Dalam sebuah organisasi perlu penataan beban kerja untuk setiap pegawai yang menjadi tanggung jawab pelaksana tugas pejabat yang ada didalamnya, sehingga dengan adanya pemerataan beban kerja pegawai dapat meningkatkan kinerja pegawai yang dapat meningkatkan kepada kinerja organisasi secara keseluruhan. Beban kerja pada pegawai UPBJJ-Universitas terbuka Bandung baik pegawai staf (administratif) maupun para tenaga edukatif secara keseharian bekerja secara bersama-sama dalam menjalankan tugas pekerjaan administratif, para tenaga edukatif tersebut diperbantukan untuk mengerjakan tugas pekerjaan administratif tanpa mengesampingkan tugas pokoknya sebagai tenaga edukatif. Adanya pembagian beban kerja pegawai yang tidak merata menjadi permasalahan terhadap kondisi kerja pegawai, bahkan ada pula pegawai yang beban kerjanya berkurang hal ini menyebabkan kerja pegawai dalam mengerjakan pekerjaannya menjadi menurun karena banyak waktu efektif kerja yang hilang disaat orang lain sibuk bekerja.Jam kerja yaitu 8.00-16.30 (jumlah jam kerjanya efektifnya perhari seharusnya adalah delapan jam tigapuluh menit), adapun tujuan dari penelitian adalah Mengetahui bagaimana permasalahan Beban Kerja Pegawai Pada Kantor UPBJJ-UT Bandung serta untuk mengetahui bagaimana kesesuaian antara Beban Kerja dengan jumlah pegawai pada UPBJJ-UT Bandung. Metode yang dipergunakan dalam penelitian ini adalah penelitian kualitatif dimana penelitian ini lebih menonjolkan data yang bersifat deskriftif analitis yang didapat dalam bentuk narasi, gambar, serta bersifat induktif dimana peneliti, membangun abstraksi, konsep hipotesa dan teori dari rincian. Analisa kualitatif yang dipakai selanjutnya adalah pembahasan dari hasil analisa beban kerja pegawai. Hubunganhubungan yang logis dijelaskan bersama beberapa teori yang ada dan hasil pengolahan data isian. Teori yang digunakan, Beban waktu (time load), Beban usaha mental (mental effort load), Beban tekanan Psikologis (psychological stress load), Tarwaka (2011:131) Berdasarkan hasil peneilitian tentang penggunaan waktu kerja yang diperlukan untuk menyelesaikan pekerjaan menunjukan bahwa meskipun semua pekerjaan selalu terselesaikan dengan baik tetapi waktu kerja pegawai pada waktu-waktu tertentu menjadi bertambah sampai diluar jam kerja maupun hari libur kerja, sehingga diperlukan penambahan pegawai yang sesuai dengan hasil perhitungan jumlah pegawai efektif yaitu penambahan sebanyak 7 orang dengan rincian 3 orang untuk bagian koordinator registrasi dan Ujian, 1 orang koordintor BLBA dan 3 orang bagian tata usaha.
\end{abstract}

\section{ABSTRACT}

Within an organization need to setup the workload for each employee whose duties are the responsibility of the implementing officials in it, so that with the distribution of the workload of employees can increase employee performance can improve the performance of the organization as a whole. Workload on employees UPBJJ Open University Bandung well - employee staff (administrative) as well as the lecturers for the daily work together in carrying out administrative

\footnotetext{
${ }^{1}$ e-mail: bambangad@ecampus.ut.ac.id

²e-mail: ridho@ecampus.ut.ac.id
} 


\begin{abstract}
work, the lecturers are assigned to administrative work tasks without compromising the main task as lecturers. The division of the workload of employees are not evenly into the problems of the working conditions of employees, and even some employees who reduced his workload this causes the employee in their work is reduced due to a lot of lost work time effectively while other people are busy working.worktime within $8.00 \mathrm{am}-16.30 \mathrm{pm}$ ( the number of effective working hours per day should be eight hours thirty minutes), The purpose of the study was to determine how the problem Workload Employee In Office UPBJJ - UT Bandung and to know how to fit between Workload by the number of employees on - UT UPBJJ Bandung. The method used in this study is a qualitative research which this study further highlight the descriptive analytical data that is obtained in the form of narratives, images, and is inductive where researchers, building abstractions, concepts, and theories from details hypotheses. Qualitative analysis was used further discussion of the analysis of the workload of employees. use the teory time load, mental effort load, psychological stress load, from Tarwaka (2011:131) Based on the results of research on the use of labor time required to complete the work shows that despite all the work is always done properly but time employees working at certain times to grow up outside of working hours and days off work, so we need additional staff in accordance with the calculation effective number of employees is the addition of 14 people with the details 3 people for registration and exam coordinator sections, BBLBA coordinator 1 and 10 for administration section.
\end{abstract}

Keyword : Workload, Employees, Open University and Methods

\section{A. PENDAHULUAN}

Dalam sebuah organisasi perlu penataan beban kerja untuk setiap pegawai yang menjadi tanggung jawab pelaksana tugas pejabat yang ada didalamnya, sehingga dengan adanya pemerataan beban kerja pegawai dapat meningkatkan kinerja pegawai yang dapat meningkatkan kepada kinerja organisasi secara keseluruhan.

Betapapun tingginya kemampuan seseorang atau pun hebatnya seorang pimpinan tidak akan dapat menyelesaikan suatu pekerjaan dengan sendiri, dan tidak ada seorang pun yang dapat menyelesaikan suatu pekerjaan dalam organisasi yang besar dengan bekerja sendirian. Dengan adanya beban kerja yang diberikan dan dapat diselesaikan dengan baik akan berpengaruh terhadap kinerja pegawai secara keseluruhan.

Dalam dunia kerja bahwa beban kerja pegawai merupakan sesuatu hal yang selalu perlu diperhatikan dan di sesuaikan dengan kemampuan dan keterampilan pegawai karena untuk meningkatkan daya saing suatu organisasi serta dapat mengefektifkan pekerjaan yang ada, itu dalam mengatur beban kerja harus dilihat dari kesiapan pegawai itu sendiri sehingga pekerjaan yang diberikan dapat dikerjakan dengan baik dan tepat waktu.. Sesuai dengan beban kerja yang menjadi tanggungjawab serta mencegah kemungkinan tumpang tindihnya pekerjaan, pemborosan dan saling melempar tanggung jawab bilamana terjadi kesalahan.

\section{Latar Belakang}

Sumber Daya Manusia (SDM) sering merupakan salah satu sorotan yang paling tajam dalam pelaksanaan pekerjaan, menyangkut kesiapan, jumlah, pendidikan, dan profesionalisme. Pelaksanaan pekerjaan yang baik merupakan tujuan dari setiap organisasi baik pemerintah maupun swasta. Sumber daya manusia merupakan faktor penting dan faktor penentu dalam sebuah organisasi, baik di organisasi swasta maupun di organisasi publik. Dikatakan sebagai faktor penentu, karena, maju mundurnya sebuah organisasi bergantung pada sumber daya manusianya. Atas dasar hal tersebut, maka dapat dikatakan bahwa sumber daya manusia di sebuah organisasi merupakan faktor penting keberadaannya.

Beban kerja yang sesuai dan merata mutlak diperlukan, sebab tanpa adanya keseuaian beban kerja jelas mereka bekerja tidak akan merata juga sebab jika beban kerja diberikan tidak sesuai dan tidak merata meyebabkan 
sebagian masih sibuk bekerja dan sebagian pegawai tidak ada pekerjaan.

Oleh karena itu dalam suatu organisasi perlu melihat terhadap kemampuan pegawai dalam rangka pemberian beban kerja yang sesuai dengan kemampuan pegawai itu sendiri. Sehingga para pegawainya untuk dapat melaksanakan tugasnya sesuai dengan beban kerja yang diberikan dengan demikian proses organisasi dapat berjalan lancar. Karena dengan adanya tugas kerja yang diemban oleh para pegawai akan menjadi lebih ringan dan memberikan kejelasan dalam pelaksanaannya sehingga pekerjaan lebih mudah dan lancar.

Beban kerja pada pegawai UPBJJUniversitas terbuka Bandung baik pegawai staf (administratif) maupun para tenaga edukatif secara keseharian bekerja secara bersama-sama dalam menjalankan tugas pekerjaan administratif, para tenaga edukatif tersebut diperbantukan untuk mengerjakan tugas pekerjaan administratif tanpa mengesampingkan tugas pokoknya sebagai tenaga edukatif.

Hasil penelitian awal mengenai beban kerja pegawai pada kantor UPBJJ-Universitas Terbuka Bandung masih terdapat permasalahan berkurang pada beban kerja yang diterima pegawai seperti :

- Adanya pembagian beban kerja pegawai yang tidak merata bahkan ada pula pegawai yang beban kerjanya hal ini menyebabkan kerja pegawai dalam mengerjakan pekerjaannya menjadi menurun karena banyak waktu efektif kerja yang hilang disaat orang lain sibuk bekerja.Jam kerja yaitu 8.00-16.00 (jumlah jam kerjanya efektifnya perhari seharusnya adalah delapan jam tiga puluh menit),

- Dikarenakan adanya pegawai yang masih sibuk dan ada pegawai yang hampir sudah tidak mendapatkan beban kerja padahal di instansi ini sudah sarat dengan sumber daya manusia khususnya di bagian Tata Usaha sebagai contoh masih adanya pegawai yang diberikan beban kerja sedikit tetapi masih saja belum dapat menyelesaikan pekerjaannya dengan baik dan tepat waktu seperti dalam rekapitulasi penyelesaian keluhan-keluhan layanan mahasiswa,dan dalam membuat la- poran-laporan pekerjaan bulanan yang harus diselesaikan masih selalu ada keterlambatan dalam penyelesaiannya.

Karena pada masing-masing tugas pekerjaan memerlukan waktu dan konsentrasi dalam melaksanakan pekerjaan tersebut untuk selesai secara maksimal. Dengan kata lain pegawai dapat bekerja secara efektif bila pegawai melakukan pekerjaan sesuai dengan beban kerja yang baik serta sesuai dengan kemampuan dan keahlian pegawai. Akibat dari beban kerja yang tidak sesuai tersebut menyebabkan pega-wai tersebut tidak dapat menyelesaikan peker-jaan sesuai waktu yang ditentukan karena sering terjadi penundaan pekerjaan sehingga berdampak pada lambatnya pekerjaan dan layanan yang diberikan kepada mahasiswa yang pada akhirnya untuk mengejar target pekerjaan, sering menggunakan waktu diluar jam kerja misalnya tambahan waktu kerja setelah jam pulang kerja atau masuk kerja pada hari libur.

Dari beberapa permasalahan tersebut kemungkinan bahwa beban kerja yang diberikan kepada pegawai pimpinan kurang melihat kepada kemampuan pegawai bahkan terkesan memberikan tugas kepada pegawai itu-itu saja, sehingga pegawai yang tidak diberi beban tugas akan merasa dirinya dianggap kurang mampu melaksanakan pekerjaannya sehingga timbul kemalasan walaupun diberikan beban kerja yang ringan sehingga dapat menurunkan kinerja pegawai tersebut. Beban kerja yang tidak merata bisa berakibat kepada menurunya kinerja pegawai.

\section{Rumusan masalah dan tujuan Penelitian}

\section{a. Rumusan Masalah}

Berdasarkan latar belakang yang telah diuraikan diatas, maka dapat dikemukakan perumusan masalah dalam penelitan ini adalah :

1. Bagaimanakah Beban Kerja Pegawai Pada Kantor Unit Program Belajar Jarak Jauh Bandung?

2. Apakah Pengaruh Beban Kerja terhadap Pegawai Pada Kantor Unit Program Belajar Jarak Jauh Bandung? 
3. Bagaimanakah penggunaan waktu kerja yang diperlukan untuk menyelesaikan tugas pekerjaan Pada UPBJJ-Universita terbuka Bandung?

\section{b. Tujuan}

1. Mengetahui bagaimana permasalahan Beban Kerja Pegawai Pada Kantor UPBJJ-UT Bandung.

2. Untuk mengetahui bagaimana kesesuaian antara Beban Kerja dengan jumlah pegawai pada UPBJJ-UT Bandung.

\section{B. TINJAUAN TEORITIS}

Menurut Sutarto dalam bukunya Dasar dasar Organisasi mengungkapkan "Bahwa beban aktivitas satuan organisasi atau beban kerja masing-masing pejabat atau pegawai hendaknya merata sehingga dapat dihindarkan adanya satuan organisasi yang terlalu banyak aktivitasnya dan ada satuan organisasi terlalu sedikit aktivitasnya demikian pula dapat dihindarkan adanya pejabat atau pegawai yang terlalu bertumpuk-tumpuk tugasnya dan ada pejabat atau pegawai yang sedikit beban kerjanya sehingga nampak terlalu banyak menganggur.” (Sutarto 2006;122)

Beban kerja akan selalu mempengaruhi terhadap kinerja pegawai baik selama proses bekerja dan setelah kerja selesai, pengertian lain yang menyatakan beban kerja adalah Munandar (2001: 383), memberikan pengertian mengenai beban kerja seperti berikut :

"Beban kerja adalah suatu kondisi dari pekerjaan dengan uraian tugasnya yang harus diselesaikan pada batas waktu tertentu. Beban kerja dapat dibedakan lebih lanjut ke dalam beban kerja berlebihan/terlalu sedikit 'kuantitatif, yang timbul sebagai akibat dari tugas-tugas yang terlalu banyak/sedikit diberikan kepada tenaga kerja untuk diselesaikan dalam waktu tertentu, dan beban kerja berlebihan/terlalu sedikit 'kualitatif', yaitu jika orang merasa tidak mampu untuk melakukan suatu tugas, atau tugas tidak menggunakan ketrampilan dan/atau potensi dari tenaga kerja."

Sedangkan pendapat lain yang menyatakan pendapat beban kerja yang menekankan kepada tuntutan tugas yang harus dikerjakan pegawai adalah dalam buku Tarwaka Beban Kerja (workload) menurut Hart \& Staveland dalam (Tarwaka 2011:106) bahwa : "Beban kerja merupakan suatu yang muncul dari interaksi antara tuntutan tugas-tugas lingkungan kerja dimana digunakan sebagai tempat kerja, keterampilan dan persepsi dari pekerja. Beban kerja kadang-kadang didefinsikan secara operasional pada faktor-faktor seperti tuntutan tugas atau upaya-upaya yang dilakukan untuk melakukan pekerjaan."

\section{METODA}

Metode yang dipergunakan dalam penelitian ini adalah penelitian kualitatif dimana penelitian ini lebih menonjolkan data yang bersifat deskriftif analitis yang didapat dalam bentuk narasi, gambar, serta bersifat induktif dimana peneliti ,membangun abstraksi, konsep hipotesa dan teori dari rincian. Analisa kualitatif yang dipakai selanjutnya adalah pembahasan dari hasil analisa beban kerja pegawai. Hubungan-hubungan yang logis dijelaskan bersama beberapa teori yang ada dan hasil pengolahan data isian.

\section{Teknik Pengumpulan Data}

Untuk memperoleh data atau informasi, keterangan-keterangan, dan data data yang diperlukan, peneliti menggunakan teknik pengumpulan data dan Instrumen sebagai berikut:

1. Teknik pengumpulan data primer adalah teknik pengumpulan data yang dilakukan secara langsung pada lokasi penelitian. Pengumpulan data primer dilakukan dengan instrumen :

a. Metode Wawancara (interview)

Yaitu teknik pengumpulan data dengan mengajukan pertanyaan secara langsung kepada Ka. Subag Tata Usaha/ Koordiantor yaitu orang yang berhubungan dengan objek penelitian, pada UPBJJ-UT Bandung.

b. Kuesioner (questionary) 
Yaitu teknik pengumpulan data yang dilaksanakan dengan cara menyebarkan daftar pertanyaan yang dilengkapi dengan beberapa alternatif jawaban yang sudah tersediadi sebarkan kepada 46 orang pegawai pada UPBJJ-UT Bandung.

\section{c. Observasi (observation)}

Yaitu kegiatan mengamati secara langsung dengan mencatat gejala-gejala yang ditemukan dilapangan serta menjaring data yang tidak terjangkau.

\section{Teknik pengumpulan}

Data sekunder adalah pengumpulan data yang dilakukan melalui studi kepustakaan yang terdiri dari:

a. Penelitian kepustakaan (library research), yaitu pengumpulan data yang diperoleh dari teori-teori yang relevan, yang memiliki relevansi dengan masalah yang diteliti.

b. Studi dokumenter (documentary),yaitu metode dengan mengumpulkan, mengidentifikasi serta mengolah data tertulis berbentuk buku-buku yang relevan, peraturan-peraturan, laporan kegiatan serta data yang relevan bagi penelitian.

\section{PEMBAHASAN}

Beban kerja merupakan hal yang penting dalam perhitungan formasi pegawai dan dapat dipakai untuk menghitung jumlah pegawai yang efisien. Jika pegawai setiap harinya dapat bekerja secara efektif maka pekerjaannya dapat selesai tepat pada waktunya. Berikut ini perhitungan waktu kerja produktif pegawai diketahui pula hari absen, izin, dan lain-lain sebesar $10 \%$ (menurut International Labor Organization dalam Suharyono dan Wiku) yang kemudian dikalikan dengan jumlah hari menurut kalender dalam 1 tahun adalah $10 \%$ x $365=36,5$ hari sehingga dibulatkan menjadi 37 hari. Hasil perhitungannya sebagai berikut :
Tabel 1 Perhitungan hari efektif dan jam efektif kerja pegawai

\begin{tabular}{|l|r|c|}
\hline \multicolumn{1}{|c|}{ Perhitungan hari kerja pegawai } & $\begin{array}{c}\text { banyak } \\
\text { hari }\end{array}$ & Total \\
\hline \hline $\begin{array}{l}\text { jumlah hari selama satu tahun } \\
\text { menurut kalender }\end{array}$ & 365 & \multirow{2}{*}{365 hari } \\
\hline Jumlah hari Sabtu dan Minggu & 104 & \multirow{2}{*}{161 hari } \\
\cline { 1 - 2 } Jumlah Hari Libur Nasional & 14 & \\
\cline { 1 - 2 } Jumlah Cuti Bersama & 37 & \\
\hline Jumlah Absen (Sakit,Izin,dll) & & \multirow{2}{*}{204 hari } \\
\hline Hari Kerja efektif dalam 1 tahun & &
\end{tabular}

\begin{tabular}{|l|l|l|}
\hline 1 hari kerja & 8 jam & \\
\hline waktu istirahat perhari & 1 jam & \\
\hline Total 1 hari kerja & & 7 jam \\
\hline
\end{tabular}

\begin{tabular}{|l|r|r|}
\hline Waktu efektif dalam 1 tahun & $80 \%$ & \\
\hline Total 1 hari kerja & & $7 \mathrm{jam}$ \\
\hline
\end{tabular}

\begin{tabular}{|l|r|r|}
\hline waktu efektif per hari & & 5,6 \\
\hline Hari Kerja efektif dalam 1 tahun & & 204 hari \\
\hline & & \\
\hline Waktu produktif dalam satu tahun & & $\begin{array}{r}1142,4 \\
\text { jam }\end{array}$ \\
\hline \hline
\end{tabular}

Sumber data: Hasil perhitungan microsoft Excell

Hasil perhitungan menunjukkan waktu produktif dalam satu tahun adalah 1142,4 jam. Perhitungan waktu produktif ini digunakan untuk menghitung jumlah pegawai yang efisien. Selain waktu produktif, untuk menghitung jumlah pegawai yang efisien dibutuhkan beban kerja pegawai. Oleh karena itu, analisis beban kerja berdasarkan deskripsi pekerjaan masing-masing pegawai sangat penting untuk diketahui. Berikut disampaikan perhitungan mengenai beban kerja pegawai yang ada pada UPBJJ-UT Bandung dengan beberapa bagian kerja yang ada.

Beban kerja pegawai masing-masing bagian akan diuraikan dari Koordiantor Registrasi dan Ujian, Koordinator Bantuan Belajar dan layanan Bahan Ajar (BBLBA) dan Kasubbag Tata Usaha. Berikut perhitungan analisia beban kerja pada UPBJJ-UT Bandung. 


\section{Beban Kerja di Bagian Koordinator Registrasi dan Ujian}

Beban kerja untuk masing-masing jabatan pegawai pada bagian koordinator Registrasi dan ujian. Pada bagian ini pekerjaan yang dilakukan adalah bersifat rutin dan berkala namun secara rata-rata pegawai lebih banyak melakukan pekerjaan yang bersifat rutin karena proses pekerjaan tersebut perlu dilakukan setiap hari meskipun pelaporannya hanya diperlukan satu atau tiga bulan sekali. Beban kerja Koordinator Regjian dalam satu tahun adalah 2586 jam. Persepsi koordinator regjian untuk pekerjaan yang dilakukan adalah beragam dari ringan sampai berat. Hal ini dikarenakan pekerjaan koordinator regjian sudah menjadi rutinitas dan telah didukung oleh data yang ada. Terdapat pula pekerjaan yang dinilai berat oleh pegawai, hal ini dikarenakan pekerjaan tersebut membutuhkan ketelitian dan perhitungan yang cermat.

Beban kerja Penanggung Jawab Registrasi dalam satu tahun adalah 5244 jam. Persepsi penanggung jawab registrasi untuk pekerjaan yang dilakukan tidak terlalu sulit karena sudah terbiasa melakukannya tetapi perlu keakuratan dalam penyelesaiannya.

Beban kerja Penanggung Jawab kasus Ujian dalam satu tahun adalah 4010 jam. Persepsi Penanggung jawab kasus untuk pekerjaan yang dilakukan adalah beragam dari ringan sampai berat. Hal ini dikarenakan pekerjaan Penanggung jawab kasus didukung oleh data yang disetorkan oleh tiap pokjar. Terdapat pula pekerjaan yang dinilai berat oleh Penanggung jawab kasus, hal ini dikarenakan pekerjaan tersebut melibatkan pokjar di bawahnya yang kadang-kadang telat memberikan data sehingga pekerjaan akan terganggu. Sedangkan untuk petugas ICT dalam satu tahun adalah 2520 jam.

\section{Beban Kerja bagian Koordinator Bantuan Belajar dan layanan Bahan Ajar (BBLBA)}

Beban kerja untuk masing-masing jabatan pegawai pada bagian koordinator BLBA. Pada bagian ini pekerjaan yang dilakukan adalah bersifat rutin dan berkala namun secara rata-rata pegawai lebih banyak melakukan pekerjaan yang bersifat rutin karena proses pekerjaan tersebut perlu dilakukan setiap hari meskipun pelaporannya hanya diperlukan satu atau tiga bulan sekali. Beban kerja Koordinator BLBA dalam satu tahun adalah 4156 jam. Persepsi koordinator BBLBA untuk pekerjaan yang dilakukan adalah beragam dari ringan sampai berat. Hal ini dikarenakan pekerjaan koordinator BBLBA sudah menjadi rutinitas dan telah didukung oleh data yang ada. Terdapat pula pekerjaan yang dinilai berat oleh pegawai, hal ini dikarenakan pekerjaan tersebut membutuhkan ketelitian dan perhitungan yang cermat.

Beban kerja Penanggung Jawab Tutorial dalam satu tahun adalah 1916 jam. Persepsi penanggung jawab tutorial untuk pekerjaan yang dilakukan tidak terlalu sulit karena sudah terbiasa melakukannya tetapi pada sub bagian ini pegawai harus memiliki pertimbangan yang baik dalam menyelesaikan permasalahan.

Beban kerja Penanggung Jawab Bahan Ajar dalam satu tahun adalah 4116 jam. Persepsi Penanggung jawab Bahan Ajar untuk pekerjaan yang dilakukan tidaklah terlalu sulit karena sudah merupakan kegiatan harian, tetapi pada bagian ini pegawai harus cermat, tepat sasaran dan cepat dalam mendistribusikan bahan ajar ke tiap pokjar yang ada.

\section{Beban Kerja bagian Tata Usaha}

Beban kerja untuk masing-masing jabatan pegawai pada bagian Tata Usaha. Pada bagian ini pekerjaan yang dilakukan adalah bersifat rutin dan berkala namun secara rata-rata pegawai lebih banyak melakukan pekerjaan yang bersifat rutin karena proses pekerjaan tersebut perlu dilakukan setiap hari meskipun pelaporannya hanya diperlukan satu atau tiga bulan sekali. Beban kerja Kepala TU dalam satu tahun adalah 1600jam. Persepsi Kepala TU untuk pekerjaan yang dilakukan adalah beragam dari ringan sampai berat. Hal ini dikarenakan pekerjaan Tata Usaha sudah menjadi rutinitas dan telah didukung oleh data yang ada. Terdapat pula 
pekerjaan yang dinilai berat oleh Pegawai, hal ini dikarenakan pekerjaan tersebut membutuhkan ketelitian dan perhitungan yang cermat seperti dalam masalah-masalah keuangan.

Beban kerja Bendahara dalam satu tahun adalah 8676 jam. Persepsi bendahara untuk pekerjaan yang dilakukan dari tingkat ringan sampai berat karena diperlukan ketelitian dan perhitungan yang akurat seperti perhitungan perhitungan keuangan.

Beban kerja Verifikator dalam satu tahun adalah 7632 jam. Verifikator untuk pekerjaan yang dilakukan tidaklah terlalu sulit karena sudah merupakan kegiatan harian, tetapi pada bagian ini pegawai harus cermat serta teliti dalam memeriksa dokumen-dokumen terutama masalah keuangan.

Beban kerja SDM dalam satu tahun adalah 5124 jam. Persepsi SDM untuk pekerjaan yang dilakukan adalah beragam dari ringan sampai berat. Hal ini dikarenakan pekerjaan SDM merupakan sub bagian yang membutuhkan kejelian serta kemampuan dalam mengorganisasi dan memonitor sumber daya yang baik.

Beban kerja Kepegawaian dalam satu tahun adalah 6303 jam. Persepsi Kepegawaian untuk pekerjaan yang dilakukan adalah beragam dari ringan sampai berat. Hal ini dikarenakan pekerjaan kepegawaian merupakan sub bagian yang mengontrol seluruh data pegawai yang ada di kantor baik pegawai tetap maupun pegawai honor selain itu pada bagian ini melayani semua bidang kepegawaian di UPBJJ- Bandung.

Persepsi pegawai yang menilai pekerjaan yang dilakukannya adalah berat jika pekerjaan tersebut membutuhkan ketelitian, ketepatan, kecepatan, konsentrasi yang tinggi, penyelesaiannya membutuhkan waktu yang cukup lama, berhubungan dengan unit lain bahkan dengan principal dan pelanggan. Sedangkan persepsi pegawai terhadap pekerjaan yang dilakukannya bernilai sedang jika pekerjaan tersebut telah didukung oleh infrastruktur atau fasilitas yang disediakan oleh organisasi, telah menjadi rutinitas dan sesuai dengan kemampuan dan keahlian yang dimiliki oleh pegawai, data atau dokumen yang dibutuhkan telah ada dan telah sesuai prosedur kerja.
Untuk pekerjaan yang dinilai ringan oleh pegawai hal ini dikarenakan pekerjaan tersebut tidak membutuhkan tenaga ekstra untuk melakukannya dan tidak terlalu membutuhkan waktu yang banyak dalam penyelesaiannya. Pekerjaan yang banyak dinilai ringan oleh pegawai adalah pekerjaan pencatatan data pegawai dan serta pengajuan-pengajuan usulan kebutuhan pegawai lainnya, karena pegawai tersebut telah merasa nyaman dengan pekerjaan yang dilakukannya.

\section{Penghitungan Beban Kerja Pegawai}

Menghitung jumlah pegawai yang efisien dilakukan dengan cara membagi jumlah beban kerja dengan waktu produktif yang dikerjakan selama satu tahun, dengan rumus sebagai berikut:

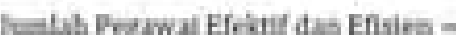

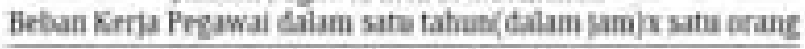

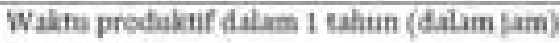

\subsection{Koordinator Registrasi dan Ujian}

a. Koordinator regjian $=\frac{2586}{1142,4}=2,26 \approx$ 2 orang.

Berdasarkan perhitungan untuk koordinator regjian diperoleh hasil bahwa jumlah pegawai yang efisien untuk bagian ini adalah 2 orang. Hasil analisis untuk bagian ini menunjukan nilai perbandingan rata rata beban kerja dianggap mencukupi dengan jumlah pegawai yang ada.

b. Penanggung Jawab Registrasi $=\frac{5422}{1142,4}=$ $4,75 \approx 5$ orang

Berdasarkan perhitungan untuk penanggung jawab registrasi diperoleh hasil bahwa jumlah pegawai yang efisien untuk bagian ini adalah 5 orang. Sedangkan untuk jumlah pegawai pada saat ini adalah 4 (empat) orang, jadi menurut hasil analisis masih diperlukan pegawai 1 orang pegawai. 
c. Penanggung Jawab Kasus Ujian $=$ $\frac{4010}{1142,4}=3,51 \approx 4$ orang

Berdasarkan perhitungan untuk penanggung jawab kasus ujian diperoleh hasil bahwa jumlah pegawai yang efisien untuk bagian ini adalah 4 orang.

Sedangkan untuk jumlah pegawai pada saat ini adalah 3 (tiga) orang, menurut hasil analisis seharusnya ada penambahan pegawai 1 orang pegawai, agar supaya pekerjaan dapat terselesaikan secara optimal.

d. Penanggung Jawab Kasus Registrasi $=$ $\frac{2928}{1142,4}=2,56 \approx 3$ orang

Berdasarkan perhitungan untuk penanggung jawab kasus registrasi diperoleh hasil bahwa jumlah pegawai yang efisien untuk bagian ini adalah 3 orang. Hasil analisis untuk bagian ini menunjukkan nilai perbandingan rata rata beban kerja dianggap mencukupi dengan jumlah pegawai yang ada.

d. ICT Koordinator BLBA $=\frac{2520}{1142,4}=$ $2,21 \approx 2$ orang

Berdasarkan perhitungan untuk koordinator regjian diperoleh hasil bahwa jumlah pegawai yang efisien untuk bagian ini adalah 2 orang. Hasil analisis untuk bagian ini menunjukan nilai perbandingan beban kerja rata rata yang dianggap mencukupi dengan jumlah pegawai yang ada.

\subsection{Koordinator BLBA}

a. Koordinator BLBA $=\frac{4156}{1142,4}=3,64 \approx$ 4 orang

Berdasarkan perhitungan untuk bagian koordinator BBLBA diperoleh hasil bahwa jumlah pegawai yang efisien untuk bagian ini adalah 4 orang.

Sedangkan untuk jumlah pegawai saat ini adalah 3 (tiga) orang, seharusnya adanya penambahan pegawai 1 orang pegawai, agar supaya pekerjaan dapat terselesaikan secara optimal

b. Penanggung jawab tutorial $=\frac{1916}{1142,4}=$ $1,68 \approx 2$ orang

Berdasarkan perhitungan untuk penanggung jawab tutorial diperoleh hasil bahwa jumlah pegawai yang efisien untuk bagian ini adalah 2 orang. Hasil analisis untuk bagian ini menunjukan nilai perbandingan beban kerja rata rata dianggap mencukupi dengan jumlah pegawai yang ada.

c. Penanggung bahan ajar $=\frac{4116}{1142,4}=$ $3,60 \approx 4$ orang

Berdasarkan perhitungan untuk penanggung jawab bahan ajar diperoleh hasil bahwa jumlah pegawai yang efisien untuk bagian ini adalah 4 orang.

Hasil analisis untuk bagian ini menunjukan nilai perbandingan beban kerja rata rata dianggap mencukupi dengan jumlah pegawai yang ada.

\subsection{Bagian Tata Usaha}

a. $\quad$ Kasubag $\mathrm{TU}=\frac{1600}{1142,4}=1,40 \approx 1$ orang

Berdasarkan perhitungan diperoleh hasil bahwa jumlah pegawai yang efisien untuk bagian ini adalah 1 orang. Nilai beban kerja yang masih berlebihan masih dapat ditangani oleh pegawai dan sebagai imbalan atas pekerjaan tersebut maka diperlukan peningkatan kompensasi maupun insentif.

b. Bendahara $=\frac{8676}{1142,4}=7,59 \approx 8$ orang 
Berdasarkan perhitungan untuk bendahara diperoleh hasil bahwa jumlah pegawai yang seharusnya untuk bagian ini adalah 8 orang. Sedangkan untuk jumlah pegawai saat ini adalah 2 (dua) orang, hasil analisis beban kerja pegawai seharusnya ada penambahan pegawai 6 orang pegawai, agar supaya pekerjaan dapat terselesaikan secara optimal dan efektif.

c. Verifikator $=\frac{7632}{1142,4}=6,68 \approx 7$ orang

Berdasarkan perhitungan untuk verifikator diperoleh hasil bahwa jumlah pegawai yang seharusnya untuk bagian ini adalah 7 orang. Sedangkan untuk jumlah pegawai saat ini adalah 4 (empat) orang jadi hasil analisis beban kerja pegawai seharusnya ada penambahan pegawai pegawai 3 (tiga) orang pegawai, agar supaya pekerjaan dapat terselesaikan secara optimal.

d. $\operatorname{SDM}=\frac{5124}{1142,4}=4,54 \approx 5$ orang

Berdasarkan perhitungan untuk bidang SDM diperoleh hasil bahwa jumlah pegawai yang seharusnya untuk bagian ini adalah 5 orang.

Sedangkan untuk jumlah pegawai saat ini adalah 4 (empat) orang, hasil analisis beban kerja pegawai seharusnya ada penambahan pegawai 1 orang pegawai, agar supaya pekerjaan dapat terselesaikan secara optimal dan efektif.

e. $\quad$ Kepegawaian $=\frac{6303}{1142,4}=5,52 \approx$ 6 orang

Berdasarkan perhitungan untuk penanggung jawab kasus diperoleh hasil bahwa jumlah pegawai yang efisien untuk bagian ini adalah 6 orang. Hasil analisis untuk bagian ini menunjukan nilai perbandingan beban kerja rata rata di anggap mencukupi dengan jumlah pegawai yang ada.

\section{Uji Validitas dan reliabilitas Instrumen Angket}

\section{Uji Validitas Instrumen Angket}

Tabel 2. Uji Validitas Instrumen Angket Beban Kerja

\begin{tabular}{|c|c|c|c|c|c|}
\hline 80 & Arative & Kerracya & Ast & Kathut & Rasharya \\
\hline 1 & $7=15$ & NT & 11 & a7ng & VT \\
\hline 1 & 9111 & 4 & 11 & Q64 & VT \\
\hline 1 & 0.4H & is & 11 & 0.411 & 13 \\
\hline 4 & 0.67 & YT & 74 & 0.411 & 12 \\
\hline 5 & 1745 & ET & 19 & 0.711 & VT \\
\hline 4 & 077 & YT & 15 & 9711 & VT \\
\hline 7 & 0712 & NT & 11 & aAll & NT \\
\hline 1 & ant & nT & 11 & ary & ns \\
\hline 1 & 0.715 & Et & 15 & 0.411 & 13 \\
\hline 10 & $0 .+4$ & 13 & 50 & 065 & 41 \\
\hline \multicolumn{2}{|c|}{ Haterahi } & \multicolumn{3}{|c|}{$4 A 4$} & VI \\
\hline
\end{tabular}

Sumber : Hasil Olahan Data Microsoft Excell 2007

Dari tabel diatas, semua item pertanyaan untuk beban kerja memiliki koefisien validitas tinggi sehingga item pertanyaan yang digunakan untuk mengukur beban kerja akan mampu menghasilkan data yang akurat sesuai dengan tujuan penelitian.

\section{Uji Reliabilitas Instrumen Angket}

Pengujian reliabilitas juga sama seperti pengujian validitas, untuk melihat apakah kuesioner yang akan digunakan untuk mengukur kompetensi pedagogik dan media pembelajaran reliabel (handal) atau tidak.

Adapun klasifikasi interpretasi koefisien reliabilitas menurut Guilford (dalam Suherman dan Sukjaya, 1990 : 177) adalah sebagai berikut :

$0,80<r_{i} \leq 1,00$ derajat reliabilitas sangat tinggi

$0,60<r_{i} \leq 0,80$ derajat reliabilitas tinggi

$0,40<r_{i} \leq 0,60$ derajat reliabilitas sedang

$0,02<r_{i} \leq 0,40$ derajat reliabilitas sangat rendah

Hasil perhitungan dapat dilihat pada tabel di bawah ini: 
Tabel 3

Hasil Pengujian Reliabilitas Beban Kerja

Pegawai

\begin{tabular}{|l|c|c|}
\hline \multicolumn{3}{|c|}{ RELIABILITAS } \\
\hline & reliabilitas & Keterangan \\
\hline $\begin{array}{l}\text { Beban } \\
\text { Kerja }\end{array}$ & 0,677 & Reliabilitas Tinggi \\
\hline
\end{tabular}

Sumber: hasil olahan data kuesioner penelitian

Tabel 4. Persepsi Pegawai terhadap Beban Kerja

\begin{tabular}{|l|l|l|}
\hline \multicolumn{1}{|c|}{$\begin{array}{c}\text { Indikator Beban } \\
\text { Kerja }\end{array}$} & \multicolumn{1}{c|}{$\begin{array}{c}\text { Skor } \\
\text { Rataan }\end{array}$} & Penilaian \\
\hline $\begin{array}{l}\text { Beban kerja sudah } \\
\text { sesuai dengan standar } \\
\text { pekerjaan }\end{array}$ & 4,00 & Setuju \\
\hline $\begin{array}{l}\text { Jumlah pegawai sudah } \\
\text { sesuai }\end{array}$ & 3,30 & Cukup setuju \\
\hline $\begin{array}{l}\text { Target yang dicapai } \\
\text { sudah jelas }\end{array}$ & 4,11 & Setuju \\
\hline $\begin{array}{l}\text { Waktu penyelesaian } \\
\text { pekerjaan sesuai }\end{array}$ & 4,19 & Setuju \\
\hline $\begin{array}{l}\text { Penyelesaian pekerjaan } \\
\text { harus dilakukan } \\
\text { dengan cepat }\end{array}$ & 4,11 & setuju \\
\hline $\begin{array}{l}\text { Pekerjaan sama tiap } \\
\text { harinya }\end{array}$ & 3,21 & Cukup setuju \\
\hline $\begin{array}{l}\text { Pada jam istirahat } \\
\text { mengerjakan pekerjaan }\end{array}$ & 3,17 & Cukup setuju \\
\hline $\begin{array}{l}\text { Meninggalkan kantor } \\
\text { ketika jam kerja telah } \\
\text { selesai }\end{array}$ & 4,11 & Setuju \\
\hline $\begin{array}{l}\text { Sangat sibuk pada } \\
\text { waktu-waktu tertentu }\end{array}$ & 4,13 & Setuju \\
\hline $\begin{array}{l}\text { Menikmati pekerjaan } \\
\text { yang dilakukan }\end{array}$ & 3,32 & Cukup setuju \\
\hline Total Rata-rata & $\mathbf{3 , 7 6}$ & Setuju \\
\hline
\end{tabular}

Berdasarkan tabel 4.3 menunjukan bahwa persepsi responden terhadap beban kerja di kantor UPBJJ UT Bandung dinilai baik. Beban kerja, kejelasan target, waktu, efektivitas penanganan pekerjaan dan disiplin waktu dinilai oleh responden sudah baik. Sedangkan intensitas dalam bekerja dinilai sudah cukup baik, namun diharapkan menjadi sebuah perhatian khusus mengenai jumlah pegawai, waktu istirahat serta jam pulang.
Tabel. 5 Jumlah total kebutuhan pegawai hasil analisis beban kerja Pegawai UPBJJ UT Bandung

\begin{tabular}{|c|c|c|c|c|}
\hline No & Bagian & $\begin{array}{c}\text { Jumlah } \\
\text { Pegawai } \\
\text { sekarang }\end{array}$ & $\begin{array}{c}\text { Jumlah } \\
\text { pegawai } \\
\text { yang } \\
\text { dibutuhkan }\end{array}$ & Keterangan \\
\hline 1 & Kepala & 1 & 1 & 16 \\
\hline 2 & $\begin{array}{c}\text { Bagian } \\
\text { Regjian }\end{array}$ & 13 & 10 & $\begin{array}{c}\text { Dibutuhkan } \\
3\end{array}$ \\
\hline 3 & $\begin{array}{c}\text { Bagian } \\
\text { BLBA }\end{array}$ & 9 & 27 & $\begin{array}{c}\text { Dibutuhkan } \\
10\end{array}$ \\
\hline 4 & $\begin{array}{c}\text { Bagian } \\
\text { TU }\end{array}$ & 17 & 3 & $\begin{array}{c}\text { Tidak ada } \\
\text { perubaan }\end{array}$ \\
\hline 5 & Office boy & 3 & 2 & $\begin{array}{c}\text { Tidak ada } \\
\text { perubahan }\end{array}$ \\
\hline 6 & Keamanan & 2 & $\begin{array}{c}\text { Tidak ada } \\
\text { perubahan }\end{array}$ \\
\hline 7 & Driver & 2 & $\mathbf{6 1}$ & $\mathbf{1 4}$ \\
\hline
\end{tabular}

Jadi jumlah kebutuhan pegawai hasil analisis dari beban kerja pegawai yang perlu di tambahkan adalah sebanyak tujuh pegawai sesuai tabel tersebut diatas, dan jumlah pegawai saat ini adalah sebanyak empat puluh tujuh pegawai yang didalamnya yaitu pegawai tetap dan tidak tetap, sehingga jika di hitung dari hasil analisis beban kerja UPBJJ-UT Bandung, untuk memperlancar pekerjaannya membutuhkan lima puluh empat pegawai, dengan demikian kelancaran dan peningkatan mutu pekerjaan akan lebih baik serta mengarah pada efisiensi waktu kerja.

\section{E. KESIMPULAN}

Berdasarkan hasil analisis beban kerja pegawai pada kantor UPBJJ Universitas Terbuka Bandung yang telah di bahas pada bab-bab sebelumnya,maka peneliti mengambil kesimpulan sebagai berikut ini:

1. Berdasarkan hasil analisis beban kerja, diperoleh bahwa terdapat perbedaan beban kerja pada masing-masing bagian di UPBJJ UT Bandung. Bagian BLBA memiliki total beban kerja paling rendah dalam setahun sedangkan Bagian Tata Usaha memiliki total beban kerja paling tinggi dalam setahun yang disebabkan banyaknya pekerjaan yang harus 
diselesaikan dengan jumlah sub bagian yang paling banyak tidak seimbang dengan jumlah pegawai yang mengakibatkan beban kerja yang diampu para pegawai menunjukan overload.

2. Berdasarkan hasil perhitungan jumlah pegawai yang efisien, maka masih terdapat ketidaksesuaian antara beban kerja dengan jumlah pegawai yang ada di UPBJJ UT Bandung, hal ini disebabkan ada beberapa bagian yang beban kerjanya mempunyai intensitas tinggi. Jumlah pegawai UPBJJ UT Bandung saat ini sebanyak 39 0rang dengan 13 pegawai bidang Registrasi dan Ujian, 9 orang Bagian Koordinator BLBA dan 17 Orang Bagian Tata Usaha.

3. Berdasarkan hasil peneilitian tentang penggunaan waktu kerja yang diperlukan untuk menyelesaikan pekerjaan menunjukan bahwa meskipun semua pekerjaan selalu terselesaikan dengan baik tetapi waktu kerja pegawai pada waktu-waktu tertentu menjadi bertambah sampai diluar jam kerja maupun hari libur kerja, sehingga jika ada penambahan pegawai yang sesuai menurut hasil perhitungan jumlah pegawai efektif untuk penambahannya yaitu dengan rincian 3 orang untuk bagian koordinator registrasi dan Ujian, 1 orang koordintor BLBA dan 10 orang bagian tata usaha.

\section{DAFTAR PUSTAKA.}

Munandar, AS. 2001. Psikologi Industri dan Organisasi. Universitas Indonesia Press, Jakarta

Menteri Pendayagunaan Aparatur Negara Republik indonesia. 2008, Peraturan Menteri Pendayagunaan Aparatur Negara Nomor : 63/PER/M.PAN/7/2008 tentang Pedoman Umum Penyelenggaraan Pelayanan Publik, Jakarta
Simamora,Henry, 2000, Manajemen Sumber Daya Manusia, STIE YKPN, Jakarta.

Sutarto, 2006, Dasar-dasar Organisasi, Gajah Mada University Press Yogyakarta

Suharyono, M W dan Wiku B. B. A. 2006. Analisis Kebutuhan Jumlah -TenagaKerja Pekarya dengan Work Sampling di Unit Layanan Gizi PelayananKesehatan Bagian Pelayanan Kesehatan St. Carolus, Jakarta. Universita Indonesia. http://www.jmpkonline.net/files/03.waseso.pdf [ 11

Agustus 2013]

Tarwaka 2011, Ergonomi Industri, penerbit : PT. Harapan Press, Solo. 